Original Article

\title{
First list of parasitoids in flies of medical, veterinary, and forensic importance in Rio Grande do Sul - Brazil
}

\author{
Primeira lista de parasitoides em moscas de importância médica, veterinária e forense \\ no Rio Grande do Sul - Brasil
}

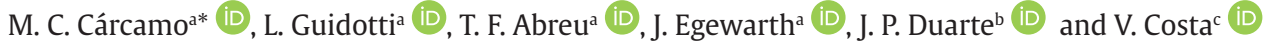 \\ a Instituto Federal de Educação, Ciência e Tecnologia Sul-rio-grandense, Laboratório de Parasitologia Veterinária, Pelotas, RS, Brasil \\ 'Universidade Federal do Rio Grande do Sul - UFRGS, Faculdade de Agronomia, Departamento de Fitossanidade, Laboratório de Biologia, Ecologia e \\ Controle Biológico de Insetos, Porto Alegre, RS, Brasil \\ 'Instituto Biológico, Agência Paulista de Tecnologia dos Agronegócios - IB-APTA, Centro Avançado de Pesquisa em Proteção de Plantas e Saúde \\ Animal, Campinas, SP, Brasil
}

\begin{abstract}
Necrophagous flies are of great importance for human and animal health. In places where their development occurs, parasitoids can be used as a tool to control these dipterans. In Brazil, the fauna of these parasitoids has been investigated in some regions. However, in Rio Grande do Sul, it is known the occurrence of only one species. Thus, this study aimed to create the first list of parasitoids in flies of medical and veterinary importance in Southern Brazil. Collections took place in the municipality of Pelotas ( $31^{\circ} 42^{\prime}$ S; $52^{\circ} 18^{\prime} \mathrm{W}$ ). Three replicates consisting of a $500 \mathrm{~g}$ bovine liver chunk placed in a tray were exposed to open air for 20 days. Then pupae were individualized and observed until their emergence. We identified 4,882 adult flies of Calliphoridae, Fanniidae, Muscidae, and Sarcophagidae. 4,040 parasitoids emerged, belonging to eight species, of which Nasonia vitripennis, Spalangia cameroni, Spalangia chontalensis, and Tachinephagus zealandicus are new records in Rio Grande do Sul state. Also, three undescribed species of the genus Aphaereta were collected. In spite of being the first attempt to inventory the fauna of hymenopteran parasitoids, this study may help in the development of management programs of these dipterans in the region.
\end{abstract}

Keywords: biological control, Diptera, forensic entomology, Hymenoptera.

\begin{abstract}
Resumo
Moscas necrófagas possuem grande importância para a sanidade humana e animal. Onde estas se desenvolvem ocorrem parasitoides que podem ser utilizados como ferramentas para o controle desses dípteros. No Brasil, a fauna desses parasitoides vem sendo investigada em algumas regiões e no Rio Grande do Sul é conhecida a ocorrência de apenas uma espécie. Portanto, o objetivo deste estudo foi criar a primeira lista de espécies de parasitoides de moscas de importância médica e veterinária ocorrentes no extremo sul do Brasil. As coletas foram realizadas no

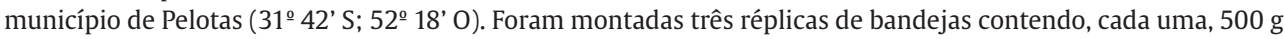
de fígado bovino, expostas ao ar livre durante 20 dias. Na sequência, as pupas foram individualizadas e observadas até a emergência. Foram identificados 4.882 adultos pertencentes às famílias Calliphoridae, Fanniidae, Muscidae e Sarcophagidae. Emergiram 4.040 parasitoides, pertencentes a oito espécies, das quais Nasonia vitripennis, Spalangia cameroni, Spalangia chontalensis e Tachinephagus zealandicus são novas ocorrências para o Rio Grande do Sul. Foram coletadas três espécies ainda não descritas do gênero Aphaereta. Apesar de ainda ser um primeiro esforço de inventariar a fauna de himenópteros parasitoides, este estudo pode auxiliar no desenvolvimento de programas de manejos desses dípteros na região.
\end{abstract}

Palavras-chave: controle biológico, Diptera, entomologia forense, Hymenoptera.

\section{Introduction}

Necrophagous dipterans are important for acting as a mechanical vector of bacteria, protozoa, helminths, and viruses to human and domestic animals (Marcondes and Thyssen, 2017), as well as for some species being able to cause myiasis (Guimarães and Papavero, 1999). Also, they are the first insects to reach the carcass, appearing in the first few hours after the death. Due to that and other aspects, they have been used as important forensic indicators (Battán Horenstein et al., 2010; OliveiraCosta et al., 2014).

*e-mail: marcialcarcamo@cavg.ifsul.edu.br

Received: May 28, 2020 - Accepted: July 14, 2020 
In places where these dipterous larvae occur, we are able to find, naturally, a rich parasitoid fauna of Braconidae, Ichneumonidae, Pteromalidae, Figitidae, Eulophidae, Chalcididae, and Diapriidae (Hymenoptera) (Sereno et al., 2016). The immature phase of these wasps uses an insect (host) as a resource, always resulting in the death of the parasitized insect. That can be caused by a toxin injected by the female wasp during oviposition, by poisoning through salivary secretion or by feeding (Quicke, 1997; Asgari and Rivers, 2011). These hymenopterans use larvae, prepupae, or pupae of flies to develop, and because of this; they are found next to the sites that the flies occur (Rivers, 2016).

Precise information on the species of these families that occur in such different ecosystems is of the utmost importance for both medical and forensic entomology (Voss et al., 2009). According to Rivers (2016), these insects can widen the PMI window to include the time after necrophagous flies cease feeding, reveal if the corpse was moved to another location prior to discovery, indicate the period of the year that death occurred and help to find concealed bodies. The information about the natural occurrence of these hymenopterans is also important to develop control strategies of these dipterans in a given region because parasitoids in high abundance are probably the most promising to rearing and mass release (Geden and Hogsette, 2006).

The knowledge about the fauna of parasitoids of necrophagous flies in Brazil is still incipient and is focused on Southeast and Mid-West regions of the country (Paiva et al., 2018; Silveira et al., 1989). The few reports on the occurrence of these insects in Southern Brazil are concentrated in Paraná (Silveira et al., 1989; Gibson, 2009) and Santa Catarina (Gibson, 2009) states. In Rio Grande do Sul, there is just one report on the occurrence of Spalangia endius Walker, 1839 (Hymenoptera: Pteromalidae) (Brandão et al., 2011). Thus, this study aimed to report the occurrence of parasitoids in flies of medical, veterinary, and forensic importance in Southern Brazil.

\section{Material and Methods}

The study was carried out in the municipality of Pelotas, Southern Brazil. The average temperature ranges from $12.3^{\circ} \mathrm{C}$ in July to $23.2^{\circ} \mathrm{C}$ in January and average annual precipitation is $1,367 \mathrm{~mm}$, with well-distributed rain throughout the year (Estação Agroclimatológica de Pelotas, 2020). The collection took place in the Instituto Federal Sul-Rio-Grandense, Câmpus Pelotas - Visconde da Graça

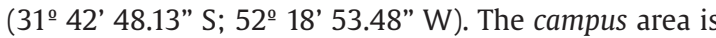
located in the city outskirts and has rural characteristics. The area is about 200 ha, where about 200 animals such as equines and bovines are raised. Also, there are some agricultural school buildings.

In the forenamed area, three collection points were chosen, with at least $150 \mathrm{~m}$ between them. A tray $(44 \times 28.5 \times 8.2 \mathrm{~cm})$ with the bottom covered with $3 \mathrm{~cm}$ of moistened sawdust was placed at each collection point. A $500 \mathrm{~g}$ piece of raw bovine liver was placed over the sawdust. Trays were monthly exposed for 20 days between
September 2017 and January 2018. After the exposure period, the trays were taken to the laboratory, where pupae were manually collected, placed individually in gelatin capsules (number 00), and kept at room temperature. Pupae were daily observed until the emergence of flies or parasitoids. If pupae have not emerged after 60 days from the collection, they were dissected to look for traces of parasitism.

Fanniidae, Muscidae, and Calliphoridae were identified with a dichotomic key proposed by, respectively, Wendt and Carvalho (2007), Carvalho (2002), and Carvalho and Mello-Patiu (2008). Parasitoid genera of Encyrtidae and Pteromalidae were identified with the dichotomic keys made by, respectively, Noyes et al. (1997) and Bouček and Heydon (1997). Parasitoid species of Tachinaephagus, Nasonia, and Spalangia were identified with dichotomic keys proposed by, respectively, Subba Rao (1978), Darling and Werren (1990), and Gibson (2009). Individuals of Braconidae were sent to Dr ${ }^{a}$. Maria Angélica Penteado-Dias.

We evaluated the number of pupae collected per month, the number of adult flies or parasitoids that emerged from each collection and the number of parasitized pupae per collection (with adult emergence or parasitism signs). We also recorded the parasitism rate (relation between the number of parasitized pupae and the total number of pupae) and the parasitism viability (relation between the number of pupae that emerged parasitoids and the number of parasitized pupae).

\section{Results}

A total of 5,899 dipterous pupae were collected, of which 4,882 have originated adult flies. A number of 426 pupae were parasitized and the parasitism rate ranged from 2.41 to $19.27 \%$ throughout the months. Of those parasitized pupae, 309 pupae had emergency of parasitoids and the parasitism viability ranged from $35.84 \%$ in December to $84.48 \%$ in September (see Table 1 ).

The flies collected belong to the families Calliphoridae, Sarcophagidae, Muscidae, and Fanniidae. Calliphoridae was the family with the highest number of species collected, represented by the genera Calliphora, Chrysomya, Lucilia, and Sarconesia. Among them, Chrysomya albiceps (Wiedemann, 1819) (Diptera: Calliphoridae) was the most abundant species (2,536 specimens). However, the most frequent species was Lucilia eximia (Wiedemann, 1819) (Diptera: Calliphoridae), collected in all the sampled months. Sarcophagidae was the second most abundant family, but the individuals were not identified at a specific level. Muscidae was represented by Musca domestica Linnaeus, 1758 (Diptera: Muscidae), Hydrotaea aenescens (Wiedemann, 1830) (Diptera: Muscidae), and Muscina stabulans (Fallen, 1817) (Diptera: Muscidae), the latter being the most abundant and frequent species of this family. Fanniidae was represented by just one genus, Fannia (see Table 2).

The parasitoids collected belong to the families Braconidae, Encyrtidae, and Pteromalidae. The family with the highest number of species was Pteromalidae, with four species, while Encyrtidae was represented 
Table 1. Pupae, adult flies, parasitized pupae number, pupae number with parasitoid emergence, parasitism rate and viability in samples collected in bovine liver in Southern Brazil.

\begin{tabular}{lccccccc}
\hline Months & $\begin{array}{c}\text { Pupae } \\
\text { number }\end{array}$ & $\begin{array}{c}\text { Adult flies } \\
\text { number }\end{array}$ & $\begin{array}{c}\text { Parasitized } \\
\text { pupae } \\
\text { number }\end{array}$ & $\begin{array}{c}\text { Pupae } \\
\text { number } \\
\text { with } \\
\text { parasitoid } \\
\text { emergence }\end{array}$ & $\begin{array}{c}\text { Parasitism } \\
\text { rate (\%) }\end{array}$ & $\begin{array}{c}\text { Parasitism } \\
\text { viability (\%) }\end{array}$ & $\begin{array}{c}\text { Mean } \\
\text { temperature } \\
(\mathbf{0} \text { ) })\end{array}$ \\
\hline September & 393 & 297 & 58 & 49 & 14.75 & 84.48 & 18.3 \\
October & 851 & 564 & 164 & 131 & 19.27 & 79.87 & 18.2 \\
November & 1,839 & 1,411 & 103 & 80 & 5.60 & 77.66 & 19.1 \\
December & 832 & 738 & 53 & 19 & 6.37 & 35.84 & 22.5 \\
January & 1,984 & 1,872 & 48 & 30 & 2.41 & 62.50 & 23.7 \\
Total & 5,899 & 4,882 & 426 & 309 & - & - & - \\
\hline
\end{tabular}

*There was a loss of one replicate due to an attack of necrophagous vertebrates to the bait.

Table 2. Number of individuals from Diptera and Hymenoptera collected in Southern Brazil.

\begin{tabular}{|c|c|c|c|c|c|c|c|c|c|c|c|}
\hline \multicolumn{2}{|r|}{ Diptera } & \multicolumn{10}{|c|}{ Months } \\
\hline Family & Genus/species & \multicolumn{2}{|c|}{ September } & \multicolumn{2}{|c|}{ October } & \multicolumn{2}{|c|}{ November } & \multicolumn{2}{|c|}{ December } & \multicolumn{2}{|c|}{ January } \\
\hline & Calliphora vicina & \multicolumn{2}{|c|}{58} & \multicolumn{2}{|c|}{61} & \multicolumn{2}{|c|}{-} & \multicolumn{2}{|c|}{-} & \multicolumn{2}{|c|}{-} \\
\hline & Chrysomya megacephala & \multicolumn{2}{|c|}{-} & \multicolumn{2}{|c|}{-} & \multicolumn{2}{|c|}{-} & \multicolumn{2}{|c|}{56} & \multicolumn{2}{|c|}{155} \\
\hline \multirow[t]{4}{*}{ Calliphoridae } & Chrysomya albiceps & \multicolumn{2}{|c|}{ - } & \multicolumn{2}{|c|}{386} & \multicolumn{2}{|c|}{631} & \multicolumn{2}{|c|}{503} & \multicolumn{2}{|c|}{1,016} \\
\hline & Lucilia eximia & \multicolumn{2}{|c|}{72} & \multicolumn{2}{|c|}{76} & \multicolumn{2}{|c|}{632} & \multicolumn{2}{|c|}{109} & \multicolumn{2}{|c|}{393} \\
\hline & Sarconesia chlorogaster & \multicolumn{2}{|c|}{27} & \multicolumn{2}{|c|}{-} & \multicolumn{2}{|c|}{ - } & & & & \\
\hline & Musca domestica & & & & & & & & & & \\
\hline Muscidae & Muscina stabulans & & & & & & & & & & \\
\hline & Hydrotaea aenescens & & & & & & & & & & \\
\hline Fanniidae & Fannia & & & & & & & & & & \\
\hline Sarcophagidae & & & & & & & & & & & \\
\hline Total & & & & & & & & & & & \\
\hline & ymenoptera & & & & & & & & & & \\
\hline Tamiln & Colu & Sep & nber & & ber & Nov & aber & Dec & aber & & ary \\
\hline & & PP & EP & PP & EP & PP & EP & PP & EP & PP & EP \\
\hline Pteromalidae & Nasonia vitripennis & - & - & 3 & 35 & 1 & 5 & - & - & 2 & 16 \\
\hline Pteromalidae & Spalangia cameroni & - & - & - & - & 21 & 21 & - & - & - & - \\
\hline Pteromalidae & Spalangia chontalensis & 9 & 9 & - & - & 9 & 9 & 1 & 1 & 24 & 24 \\
\hline Pteromalidae & Spalangia endius & 13 & 13 & 1 & 1 & 30 & 30 & - & - & - & - \\
\hline Encyrtidae & Tachinaephagus zealandicus & 15 & 204 & 124 & 3,126 & 15 & 204 & 18 & 263 & 3 & 29 \\
\hline Braconidae & Aphaereta sp nov. 1 & 10 & 10 & 3 & 3 & 3 & 3 & - & - & 1 & 1 \\
\hline Braconidae & Aphaereta sp nov. 2 & 2 & 15 & - & - & - & - & - & - & - & - \\
\hline Braconidae & Aphaereta sp nov. 3 & - & - & - & - & 1 & 18 & - & - & - & - \\
\hline Total & & 49 & 251 & 131 & 3,165 & 80 & 290 & 19 & 264 & 30 & 70 \\
\hline
\end{tabular}

$\mathrm{PP}$ - parasitized pupae number; EP - emerged parasitoid number.

only by Tachinaephagus zealandicus Ashmead, 1904 (Hymenoptera: Encyrtidae). Notwithstanding, Encyrtidae was the family with the highest number of individuals and was collected in all months. The number of collected species varied within the months, of which November had the highest richness - seven species - and December, the lowest richness - two species (see Table 2 ).

For the first time in Rio Grande do Sul, the occurrence of Nasonia vitripennis (Walker 1836) (Hymenoptera: Pteromalidae), Spalangia cameroni Perkins, 1910 (Hymenoptera: Pteromalidae), Spalangia chontalensis 
Cameron, 1884 (Hymenoptera: Pteromalidae), and $T$. zealandicus (see Table 2) was reported. Furthermore, three undescribed species of Aphaereta were found.

\section{Discussion}

The dipterans reported in this study are commonly found in Southern Brazil, in livestock farming areas (Vianna et al., 1998; Bicho et al., 2004; Azevedo and Krüger, 2013) as well as in decomposing carcasses (Souza et al., 2008; Anjos et al., 2010).

Calliphoridae family has dominated the necrophagous dipteran community. This taxon is commonly found in faunal succession in forensic studies using human corpses (Carvalho et al., 2000) or animal models (Carvalho et al., 2000; Battán-Horenstein et al., 2012). The most abundant species, C. albiceps and L. eximia, are both indicated as potential tools to estimate post mortem interval in forensic entomology (Vasconcelos and Araujo, 2012; Sanford et al., 2014). Besides, they are important species that can cause myiasis (Sanford et al., 2014) and act as a mechanical vector for human pathogens (Greenberg, 1971).

The parasitoids identified in this study have already been reported in Brazil. However, only S. endius was recorded in Rio Grande do Sul (Brandão et al., 2011). The most southern state where S. cameroni and S. chontalensis had been found so far was Santa Catarina, while N. vitripennis and T. zealandicus were reported in São Paulo and Paraná, respectively (De Santis, 1980; Silveira et al., 1989; Lecheta and Luz, 2015). Thus, our study extends the occurrence area of these four species until the southernmost state of the country.

The high abundance and frequency of $T$. zealandicus, plus its ability to infest important fly species, such as $M$. domestica (Legner, 1967), Cochliomyia hominivorax Coquerel, 1858 (Diptera: Calliphoridae) (Silveira et al., 1989), Stomoxys calcitrans (Linnaeus, 1758) (Diptera: Muscidae) (Costa, 1989), Chrysomya putoria (Wiedemann, 1830) (Diptera: Calliphoridae) (Monteiro and Prado, 2000), Sarconesia chlorogaster Wiedemann, 1830 (Diptera: Calliphoridae) (Lecheta and Luz, 2015) and Chrysomya megacephala (Fabricius, 1794) (Diptera: Calliphoridae) (Moretti and Ribeiro, 2006), make this species a potential biological control agent of these dipterans in Southern Brazil.

The constancy of S. endius, S. cameroni, and N. vitripennis populations throughout the months in Rio Grande do Sul, in addition to the fact that these species have already been commercialized in the United States and Canada (Lebeck and Leppla, 2020), shows that they are potential biological control agents of flies for integrated pest management programs in the area of this study.

Although there is a lack of knowledge about the biology, ecology, and behavior of $S$. chontalensis, this species seems to be important in the population dynamics of necrophagous flies in Southern South America, because it has already been reported in Argentina, Paraguay, and Uruguay (Gibson, 2009) and it was the solitary parasitoid most frequently collected throughout the months in this study.

Among the collected parasitoids, only $N$. vitripennis and T.zealandicus have already been reported in a forensic case study (Turchetto and Vanin, 2004). According to Rivers
(2016), the potential use of parasitoids of necrophagous flies as forensics evidence is still not very explored due to the lack of knowledge about the biology, ecology, and behavior of these species. The occurrence of $N$. vitripennis, S. cameroni, S. chontalensis, and S. endius in just some months can be important from the forensic point of view because seasonality is especially useful to determine if a corpse was removed from the crime scene (Rivers, 2016).

In spite of being performed in just one area, this study was able to report three species from the genus Aphaereta that have not been described yet. Besides, four new occurrences of parasitoids of necrophagous flies in Southern Brazil were reported, and the diversity of this group in this area is likely to be even bigger. Thus, it is of utmost importance that other studies are carried out in this region, once they are important insects for biological control and forensic entomology.

\section{Acknowledgements}

The authors thank the financial support received by the second author from Instituto Federal Sul-Rio-Grandense (IFSul) (Edital PROPESP/IFSul - N 02/2017), by the third author from Fundação de Amparo à Pesquisa do Estado do Rio Grande do Sul (FAPERGS), and by the fifth author from Conselho Nacional de Desenvolvimento Científico e Tecnológico (CNPq) (process nº 163267/2015-4). They also thank Prof ${ }^{a}$. Dr ${ }^{\mathrm{a}}$. Maria Angélica Penteado-Dias for identifying Braconidae species.

\section{References}

ANJOS, V.A., RIBEIRO, P.B., KRÜGER, R.F. and SILVA, A.Z., 2010. Ocorrência de muscóideos necrófagos em carcaça de Didelphis albiventris Lund, 1841 (Didelphimorphia, Didelphidae) no Rio Grande do Sul, Brasil. Biotemas, vol. 23, no. 2, pp. 211-214. http:// dx.doi.org/10.5007/2175-7925.2010v23n2p211.

ASGARI, S. and RIVERS, D.B., 2011. Venom proteins from endoparasitoid wasps and their role in host-parasite interactions. Annual Review of Entomology, vol.56, no. 1, pp.313-335. http://dx.doi.org/10.1146/ annurev-ento-120709-144849. PMid:20822448.

AZEVEDO, R.R. and KRÜGER, R.F., 2013. The influence of temperature and humidity on abundance and richness of Calliphoridae (Diptera). Iheringia, vol. 103, no. 2, pp. 145-152. http://dx.doi. org/10.1590/S0073-47212013000200010.

BATTÁN HORENSTEIN, M., XAVIER LINHARES, A., ROSSO DE FERRADAS, B. and GARCÍA, D., 2010. Decomposition and dipteran succession in pig carrion in central Argentina: ecological aspects and their importance in forensic Science. Medical and Veterinary Entomology, vol. 24, no. 1, pp. 16-25. http://dx.doi. org/10.1111/j.1365-2915.2009.00854.x. PMid:20377727.

BATTÁN-HORENSTEIN, M.B., ROSSO, B. and GARCÍA, M.D., 2012. Seasonal structure and dynamics of sarcosaprophagous fauna on pig carrion in a rural area of Cordoba (Argentina): their importance in forensic science. Forensic Science International, vol. 217, no. 1-3, pp. 146-156. http://dx.doi.org/10.1016/j. forsciint.2011.10.043. PMid:22138029.

BICHO, C.L., ALMEIDA, L.M., RIBEIRO, P.B. and SILVEIRA JÚNIOR, P., 2004. Flutuação de Diptera em granja avícola, Pelotas, Rio Grande do Sul, Brasil. Iheringia, vol. 94, no. 2, pp. 205-210. http:// dx.doi.org/10.1590/S0073-47212004000200013. 
BOUČEK, Z. and HEYDON, S.L., 1997. Pteromalidae. In: G.A.P. GIBSON, J.T. HUBER and J.B. WOOLLEY, eds. Annotated keys to the genera of Nearctic Chalcidoidea (Hymenoptera). Ottawa: NRC Research Press, pp. 541-692.

BRANDÃO, R.K., CÁRCAMO, M.C., COSTA, V.A. and RIBEIRO, P.B., 2011. Ocorrência de Spalangia endius Walker, 1839 (Hymenoptera, Pteromalidae) em pupas de Musca domestica L. eStomoxys calcitrans L. (Diptera, Muscidae) no sul do Rio Grande do Sul. Arquivo Brasileiro de Medicina Veterinária e Zootecnia, vol. 62, no. 1, pp. 270-272. http://dx.doi.org/10.1590/S0102-09352011000100041.

CARVALHO, C.J.B. and MELLO-PATIU, C.A., 2008. Key to the adults of the most common forensic species of Diptera in South America. Revista Brasileira de Entomologia, vol. 52, no. 3, pp. 390-406. http://dx.doi.org/10.1590/S0085-56262008000300012.

CARVALHO, C.J.B., 2002. Muscidae (Diptera) of the Neotropical Region: taxonomy. Curitiba: Editora da Universidade Federal do Paraná. 287 p.

CARVALHO, L.M.L., THYSSEN, P.J., LINHARES, A.X. and PALHARES, F.A.B., 2000. A checklist of arthropods associated with pig carrion and human corpses in Southeastern Brazil. Memorias do Instituto Oswaldo Cruz, vol. 95, no. 1, pp. 135-138. http://dx.doi. org/10.1590/S0074-02762000000100023. PMid:10656720.

COSTA, V.A., 1989. Parasitóides pupais (Hymenoptera: Chalcidoidea) de Musca domestica L. 1758, Stomoxys calcitrans (L. 1758) e Muscina stabulans (Fallén, 1816)(Diptera: Muscidae) em aviários de Echaporã, SP. Piracicaba: Escola Superior Luiz de Queiroz, 55 p. Dissertação de Mestrado em Ciências Biológicas (Entomologia).

DARLING, D.C. and WERREN, J.H., 1990. Biosystematics of Nasonia (Hymenoptera: Pteromalidae): two new species reared from birds' nests in North America. Annals of the Entomological Society of America, vol. 83, no. 3, pp. 352-370. http://dx.doi. org/10.1093/aesa/83.3.352.

DE SANTIS, L., 1980. Catalogo de los Himenopteros Brasileños de la Serie Parasitica incluyendo Bethyloidea. Curitiba: Editora da Universidade Federal do Paraná. 395 p.

ESTAÇÃO AGROCLIMATOLÓGICA DE PELOTAS, 2020 [viewed 10 January 2020]. Normais climatológicas [online]. Available from: http://agromet.cpact.embrapa.br/estacao/mensal.html

GEDEN, C.J. and HOGSETTE, J.A., 2006. Suppression of house flies (Diptera: Muscidae) in Florida poultry houses by sustained releases of Muscidifurax raptorellus and Spalangia cameroni (Hymenoptera: Pteromalidae). Environmental Entomology, vol. 35, no. 1, pp. 75-82. http://dx.doi.org/10.1603/0046225X-35.1.75.

GIBSON, G.A.P., 2009. Revision of New World Spalangiinae (Hymenoptera: pteromalidae). Zootaxa, vol. 2259, no. 1, pp. 1-159. http://dx.doi.org/10.11646/zootaxa.2259.1.1.

GREENBERG, B., 1971. Flies and disease. Princeton: Princeton University Press, vol. 1: Ecology, classification and biotic associations, $856 \mathrm{p}$.

GUIMARÃES, J.H. and PAPAVERO, N., 1999. Myiasis in man and animals in the Neotropical region. São Paulo: Plêiade/FAPESP, 308 p.

LEBECK, L.M. and LEPPLA, N.C., 2020 [viewed 28 January 2020]. Guidelines for purchasing and using commercial natural enemies and biopesticides in North America [online]. Florida: Institute of Food and Agricultural Sciences/University of Florida. Available from: http://edis.ifas.ufl.edu/in849.

LECHETA, M.C. and LUZ, D.R., 2015. First record of Tachinaephagus zealandicus Ashmead, 1904 (Hymenoptera: Encyrtidae) parasitizing the blowfly Sarconesia chlorogaster (Wiedemann, 1830) (Diptera: Calliphoridae) in Brazil. Brazilian Journal of Biology = Revista Brasileira de Biologia, vol. 75, no. 2, pp. 506. http://dx.doi.org/10.1590/1519-6984.21214. PMid:26132042.
LEGNER, E.F., 1967. Behavior changes the reproduction of Spalangia cameroni, S. endius, Muscidifurax raptor, and Nasonia vitripennis (Hymenoptera: Pteromalidae) at increasing fly host densities. Annals of the Entomological Society of America, vol. 60, no. 4, pp. 819-826. http://dx.doi.org/10.1093/aesa/60.4.819.

MARCONDES, C.B. and THYSSEN, P.J., 2017. Flies. In: C.B. Marcondes, ed. Arthropod Borne Diseases. Cham: Springer, pp. 475-502.

MONTEIRO, M.R. and PRADO, A.P., 2000. Ocorrência de Trichopria sp. (Hymenoptera: Diapriidae) atacando pupas de Chrysomya putoria (Wiedemann) Diptera: Calliphoridae) na granja. Anais da Sociedade Entomológica do Brasil, vol. 29, no. 1, pp. 159-167. http://dx.doi.org/10.1590/S0301-80592000000100020.

MORETTI, T.C. and RIBEIRO, O.B., 2006. Encontro do parasitóide Tachinaephagus zealandicus (Ashmead) (Hymenoptera: Encyrtidae) em pupas de Chrysomya megacephala (Fabricius) (Diptera: Calliphoridae) em carcaça de rato. Arquivo Brasileiro de Medicina Veterinária e Zootecnia, vol. 58, no. 1, pp. 137-140. http://dx.doi.org/10.1590/S0102-09352006000100022.

NOYES, J.S., WOOLLEY, J.B. and ZOLNEROWICH, G., 1997. Family Encyrtidae. In: G.A.P. GIBSON, J.T. HUBER and J.B. WOOLLEY, eds. Annotated keys to the Genera of Nearctic Chalcidoidea (Hymenoptera). Ottawa: National Research Council Canada Press, pp. 170-320.

OLIVEIRA-COSTA, J., LAMEGO, C.M.D., COURI, M.S. and MELLOPATIU, C.A., 2014. Differential Diptera succession patterns onto partially burned and unburned pig carrion in southeastern Brazil. Brazilian Journal of Biology = Revista Brasileira de Biologia, vol. 74, no. 4, pp. 870-876. http://dx.doi.org/10.1590/15196984.06113. PMid:25627597.

PAIVA, H.A.S., RODRIGUES-GUIMARÃES, R., BARBOSA, J.V. and PINTO, Z.T., 2018. Parasitoides de moscas no Parque Municipal Natural de Nova Iguaçu, RJ - Brasil. EntomoBrasilis, vol. 11, no. 1, pp. 52-55. http://dx.doi.org/10.12741/ebrasilis.v11i1.716.

QUICKE, D.L., 1997. Parasitic wasps. London: Chapman and Hall, 470 p.

RIVERS, D.B., 2016. Parasitic Hymenoptera as Forensic Indicator Species. In: B.S. SHETTY and J.R. PADUBIDRI, eds. Forensic analysis: from death to justice. London: IntechOpen Limited, pp. 67-83. http://dx.doi.org/10.5772/62501.

SANFORD, M.R., WHITWORTH, T.L. and PHATAK, D.R., 2014. Human wound colonization by Lucilia eximia and Chrysomya rufifacies (Diptera: Calliphoridae): myiasis, perimortem, or postmortem colonization? Journal of Medical Entomology, vol. 51, no. 3, pp. 716-719. http://dx.doi.org/10.1603/ME13229. PMid:24897868.

SERENO, A.P., SALVO, A. and BATTÁN-HORENSTEIN, M., 2016. Trophic interactions between parasitoids and necrophagous flies in Central Argentina. Acta Tropica, vol. 162, pp. 229-232. http:// dx.doi.org/10.1016/j.actatropica.2016.07.005. PMid:27423397.

SILVEIRA, G.A.R., MADEIRA, N.G., AZEREDO-ESPIN, A.M.L. and PAVAN, C., 1989. Levantamento de microhimenópteros parasitóides de dipteros de importância médico-veterinária no Brasil. Memorias do Instituto Oswaldo Cruz, vol. 84, suppl. 4, pp. 505-510. http:// dx.doi.org/10.1590/S0074-02761989000800089.

SOUZA, A.S.B., KIRST, F.D. and KRÜGER, R.F., 2008. Insects of forensic importance from Rio Grande do Sul state in southern Brazil. Revista Brasileira de Entomologia, vol. 52, no. 4, pp. 211-214. http://dx.doi.org/10.1590/S0085-56262008000400016.

SUBBA RAO, B.R., 1978. A revision of Tachinaephagus Ashmead (Hymenoptera: Encyrtidae) with descriptions of four new species. Bulletin of Entomological Research, vol. 68, no. 1, pp. 65-73. http://dx.doi.org/10.1017/S000748530000715X.

TURCHETTO, M. and VANIN, S., 2004. Forensic evaluations on a crime scene with monospecific necrophagous fly population infected by two parasitoid species. Aggrawal's International Journal of Forensic Medicine and Toxicology, vol. 5, pp. 12-18. 
VASCONCELOS, S.D. and ARAUJO, M.C.S., 2012. Necrophagous species of Diptera and Coleoptera in northeastern Brazil: state of the art and challenges for the Forensic Entomologist. Revista Brasileira de Entomologia, vol. 56, no. 1, pp. 7-14. http://dx.doi. org/10.1590/S0085-56262012005000014.

VIANNA, E.E.S., BRUM, J.G.W., RIBEIRO, P.B., BERNE, M.E.A. and SILVEIRA-JUNIOR, P., 1998. Synanthropy of Calliphoridae (Diptera) in Pelotas, Rio Grande do Sul State, Brazil. Revista Brasileira de Parasitologia Veterinária, vol. 7, no. 2, pp. 141-147.
VOSS, S.C., SPAFFORD, H. and DADOUR, I.R., 2009. Hymenopteran parasitoids of Forensic importance: host associations, seasonality, and prevalence of parasitoids of carrion flies in Western Australia. Journal of Medical Entomology, vol. 46, no. 5, pp. 1210-1219. http:// dx.doi.org/10.1603/033.046.0532. PMid:19769056.

WENDT, L.D. and CARVALHO, C.J.B., 2007. Taxonomia de Fanniidae (Diptera) do sul do Brasil-I: nova espécie e chave de identificação de Euryomma Stein. Revista Brasileira de Entomologia, vol.51, no. 2, pp. 197-204. http://dx.doi.org/10.1590/S0085-56262007000200009. 